\title{
Empowering Writing Subject
}

\author{
Erizal Gani1,** \\ ${ }^{1}$ Indonesian Language and Literature Department, Universitas Negeri Padang, Padang, Indonesia \\ *Corresponding author. Email: erizal.gani@fbs.unp.ac.id
}

\begin{abstract}
This paper discusses the empowerment of learning to write. The topic was chosen because until now (and in the future), the writing skills of our students are still far from expectations. Students have very little publication of literary works or mass media writings because they find it difficult to produce writings even at a simple level. In fact, the estuary of learning Indonesian is language skills (especially writing). Why are students less/unskilled in writing? One answer is the lack of frequency of writing. What efforts need to be made to minimize these deficiencies or incompetence? In this regard, this paper is necessary. The focus of this study is on empowering learning to write. The experience of the author who has fostered learning to write for a dozen years has also enriched the analysis of the problems raised. With such discussion, it is hoped that this paper will be one of the solutions to the weaknesses of our students in writing.
\end{abstract}

Keywords: empowerment, writing, learning

\section{INTRODUCTION}

When there is an announcement regarding a scientific writing competition, short story or poetry writing competition, or other writing competition, the reaction of students often falls to unenthusiasm. When they are required to be school delegates, they are not very enthusiastic, even often refuse (compare with their enthusiasm for participating in science competitions).

Until now (maybe until later), the writing skills of our students are still a hot topic of discussion about the quality of Indonesian language learning. In fact, the estuary of the goal of learning Indonesian is language skills, which incidentally includes writing skills. Other skills are listening, speaking, reading, observing and presenting.

Observing the low level of students' writing skills, various improvements and changes have been made by the government (in this case the Ministry of National Education). Various scientific meetings, upgrading, workshops, seminars, and others, as well as training for writing supervisors have also been carried out. All these efforts cost a lot of funds. Even though the various improvement efforts have been carried out, the writing skills of our students are still weak or seem to be standing still.

Why can this happen? Is there something that is not right in our learning to write? What other efforts need to be made to minimize/eliminate these writing deficiencies or incompetence? In connection with the above questions, this paper needs to be written. Hopefully this paper can increase our awareness of the world of writing. More than that, it should be useful knowledge. Aamiin Allahuma Aamiin.

\section{DISCUSSION}

\subsection{Students' Writing Skills}

Writing can be analogous to a bridge, a pod, or a mouthpiece. Through a writing, a reader will be able to understand the message conveyed by a writer. If the bridge is fragile, has holes, or is about to break, then the process of crossing it will definitely be problematic. Similar with writing, if the writing has a lot of "mistakes", then the reader will find it difficult to fully understand and even read it.

In fact, these "errors" are often found in the writings of our students. Even though they have gone through various stages of learning to write, namely when they take part in Indonesian language learning. Not only now, this has also happened in the past. As a result, negative statements often accompany the quality of the learning.

In this regard, in the book Cakrawala Bahasa Indonesia, Badudu argues that until now, the public has never been satisfied with the results of learning Indonesian in schools. Starting from elementary school 
to high school, even to college [1]. Referring to Sumardi, Badudu also explains that in the world of education, language skills (writing) need to be under more pressure [1]. This is due to the low ability to speak Indonesian (written) both among students and among teachers.

Badudu's above opinion, which has long been mentioned, is not an exaggeration. Actually, the same opinion has long been and is often addressed in Indonesian language learning (especially in writing learning). The reality shows that the writing ability of our students is in poor category. From several meetings and discussions with Indonesian language teachers, this matter was often discussed. Not only in students and even among educators too.

Akhadiah et al. [2] suggests that the problem that is often raised in learning to write is the inability of students and students to use Indonesian properly and correctly. This can be seen from the choice of words (diction) that are less precise, sentences that are less effective, it is difficult to express ideas, difficult to choose words when making sentences, even less able to develop ideas in an orderly and systematic manner. In addition, spelling errors are the most common mistakes.

All of the opinions above are clearly a challenge, they can even be a hard "slap" for various parties. Why is all this troubling still around? Where did the source come from? And who is responsible for all this? The series of questions above require us to self-correct and "reflect" on what our Indonesian teachers have done.

Based on observations and open interviews (not a research) that the author conducted with Indonesian language teachers on the sidelines of MGMP and/or PPG activities, varied valuable information are obtained. The conclusion from the information is narrowed down to the following reasons, namely: (1) curriculum, (2) teacher knowledge and abilities, (3) knowledge, talents, and abilities of learners, (4) approaches and teaching systems, (5) schools, (6) climate, and (7) there are assumptions about that the provision and ability to write children are not properly nurtured at the previous level of education. Regardless of whether the information is correct or not, it is clear that these things (and other things) remain an input that should be considered and a solution should be sought.

\subsection{Situation in Learning to Write}

Writing is one of the four aspects of language skills. Other aspects of language are listening, speaking, and reading. In curriculum 13 (K13 or Kurtilas) it is explained that observing and presenting are included in aspects of language skills that must be possessed by students.

According to Rusyana writing is the ability to use language patterns in its written delivery to express an idea or message [3]. On another opinion, writing or composing is a process in describing a language that can be understood by someone [4].

Some recent opinions about writing are not much different from the two opinions above. All of these opinions show that writing is a symbolizing activity (compare with speaking as an activity of reciting). When examined further, it turns out that writing activities are not just symbolizing what is contained in the world of ideas or ideas, or not just symbolizing the spoken pronunciation. Writing goes far beyond all that. Writing is a high-level communication process. It is a container in which various understandings and expertise are intertwined. With these demands, it is hoped that someone (the author) can communicate ideas, thoughts, feelings, and opinions well. Through such writing, the reader understands the various messages contained in an article.

As part of the act of language, writing is closely related to the thought process. The relationship between writing and thinking can be likened to two sides of the same coin. In other words, the separation between writing ability and thinking ability is very thin.

In line with the above, according to Costa writing and thinking are two activities that are implemented repeatedly. Writing is a tool that is also the result of a thought. Through a writing, a person (the writer) can communicate his ideas and ideas permanently; On the other hand, through thinking activities, a person can improve his writing skills [5]. Weaknesses in one of these two aspects can have a negative impact on the results of a piece of writing. Thus, it is clear that there is a close relationship between the ability to write and the ability to think.

Expressing ideas in writing is not easy. This is because many things affect it. In addition to being required to have adequate thinking skills, writing also involves various skills, attitudes, and knowledge that must be mastered first. When a writer wants to write about something (for example, about filial piety to parents), then (at least) he must (1) understand and sort out the main issues that are communicated, (2) understand and skillfully use linguistic devices, (3) mastering and skilled in writing, (4) having high target motivation, and (5) prepare facilities and other 
supporting factors, (6) thoroughness, accuracy, insight, and so on. In addition, the frequency or high frequency of writing also determines the quality of the writing produced by a person.

Writing is not an easy job. At least according to Harris [6] a writer must master the following components, including: (1) writing content, (2) writing organization, (3) linguistic or grammatical problems, (4) writing style, and (5) writing mechanism [7]. Failure to master one of the five components can be a stumbling block in expressing concept, ideas, or thoughts in writing.

Based on the description and limitations above, it is clear that writing activities are not just symbolizing spoken language into written language patterns. That is, not just translating spoken language into written language, or not just writing what should be said. Writing is a process of communicating a thought or idea based on certain rules.

Formally, the development of writing skills has been started since elementary school (SD) which is in the form of learning to write for beginners. At this very early age, students are introduced to symbols of letters, numbers, and other written signs (punctuation). Gradually, students are introduced, trained, fostered, and developed their writing potential. They are nurtured in such a way with the hope that they will have adequate provisions for further writing activities. Good coaching and development from an early age is a solid foundation for students in pursuing writing achievements at higher education levels.

Even though the development of writing skills has been started since elementary school, the reality shows that for most of our students writing is not an easy task. This can be seen from several issues raised at the beginning of this paper. From previous interviews with several Indonesian language teachers at different levels of education and from the observations of the author who has fostered the teaching of writing for a dozen years, It can be said that some of the problems surrounding learning to write can cause students to be less proficient in writing. In his opinion, these things are as follows.

First, the curriculum in the field of Indonesian language studies currently used is the K 13 Curriculum (K 13 or Kurtilas). The curriculum (and several previous curricula) always emphasizes aspects of language, not "on the language itself'. That is, the portion of language learning must emphasize aspects of language (listening to speaking, reading, writing, observing, and presenting). With such a mandate, students are expected to have skills in every language activity. In reality, these learning objectives are very difficult to achieve because there are so many subject matter that must be taught and the limited time available.

Some teachers think that our current curriculum is filled with material that must be taught. This is further exacerbated by the high demands of each (each) subject curriculum. Students must meet the high demands of each subject, so that they lack/do not have sufficient time to hone their writing potential. This is further exacerbated by the tendency of students to focus more on certain subjects such as English and science (mathematics, physics, biology, and chemistry). So, they spend a lot of time and energy to pursue the field of study concerned. Not only at school, outside they also spend a lot of time to add depth to these subjects. This condition is certainly not favorable for the development of students' writing potential. They are preoccupied with the problems that emphasize only logical thinking.

The second is the problem of the ability of teachers who generally do not have a good foundation of ability in writing. The competence and (especially) the performance of teachers in writing are generally not good enough (if not bad). Very few teachers are good at writing or become a writer. Rarely do our teachers conduct research which ultimately gives birth to a written work. That is why not many written works (scientific or non-scientific) are produced by our teachers. When asked to write, various reasons were put forward so that the request was not addressed to them. When they attend seminars (for example), they are only listeners, not presenters. In short, the writing climate has not grown in most of our teachers.

This poor writing ability does not only occur among Indonesian language teachers; The teachers of other subjects did the same. Generally, our teachers' writing background is very weak. Apart from writing questions for the exams, they produce almost no other written work. Although the government rewards their writing in the form of credit points for promotion, even though they master the subject matter because they have taught dozens or even decades, they are still unable to produce a qualified writing. This condition is not very conducive to fostering a writing climate in a school.

Third, learning to write often uses ineffective approaches, methods, strategies, and techniques. Often, teachers position writing as a knowledge tool, not a skill. The consequence of such thinking is the use of 
inappropriate learning methods and techniques. Teachers often teach theory about writing, not train students to write. Teachers are more likely to lecture, not practice writing. Such an approach and technique is clearly not a conducive condition for proficient children in writing. The principle of learning like this is of course very contrary to the nature of learning Indonesian which emphasizes the language aspect.

Actually, Indonesian language teachers are very aware of the need for writing training. However, considering the various subject matter that students must understand, and limited time in training, checking, and discussing student assignments, teachers often use less precise techniques or learning methods. This is further exacerbated by the "a lot" of administrative demands that our teachers have to fulfill.

A person will not be skilled at cycling if he is only taught about cycling procedures. He had to go up and down in training to ride a bicycle. Learning from experience and practicing continuously is what makes them capable and skilled at cycling. Reliable footballers such as Leonel Messi, Ronaldo, or other soccer players will not be skilled and have high technique in playing football if they are only taught about the theory of playing football. They actually become great because almost every day they struggle and continue to struggle with the ball. It's the same with writing. Writing is not just theorizing. Writing is a process and must always be a process. Therefore, writing practice is very necessary in every writing lesson. Only by practicing and correcting the results of these exercises a student will be skilled at writing. Do not teach students with any writing theories. That is, the portion of writing practice should be more than the portion of writing theory.

Fourth is the problem of students. In general, the ability of students to understand elements of written language such as spelling, choice of words (diction), sentences, paragraph arrangement, writing, and organization of thought development into an essay is not enough. In fact, this aspect of writing theory has been studied since elementary education. Mastery of basic theories in writing is very necessary in giving birth to a student who is skilled in writing. Due to their weak knowledge of writing, they often write carelessly. Although writing is a process, however, the process must be based on a good theory, especially for scientific papers.

Kurtilas does require students to be skilled at writing. It is the students who are required to be skilled at writing. They are the ones who must understand the theory and implement it in the writing process. Therefore, the motivation to write must come from them (students). If that awareness did not exist in them, of course, no writing would be produced. Even if there is, of course the quality of the writing is low.

Students' appreciation and attitudes towards writing activities, in general, are poor or not very good. This can be observed from various things, for example the low motivation of the target (prospective writer). The average student or our students just write when they are required to write. They just wrote (paper or thesis) because the writing is one of the requirements for graduation. Even when they write, they are less enthusiastic. When there are obstacles, they quickly give up or copy existing writings. Target motivation, enthusiasm, and never give up are reliable "ammunition" in producing a piece of writing. If these things are lacking or absent, the writing power will also weaken. In the end, writing is of poor quality or nothing at all. So, mastering writing theory and understanding written material must be balanced by a strong target motivation.

Fifth is the school factor. Schools and their environment must have great attention to foster the habit of writing. This attention can be in the form of providing adequate facilities and infrastructure (e.g. computers and internet), providing facilities, award for each writing publication, create relevant programs (eg monthly writing programs, writing competition programs, etc.), school magazines, various collaborations, and so on. So far, many schools have not created conducive conditions for the growth and development of a love of writing. As a result, it is reasonable that the writing skills of teachers and students in these schools are very low. Another thing that is no less important is the views of the teachers. Generally, teachers assume that writing activities are the responsibility of teachers in the field of Indonesian language studies. They only care about the subjects they teach. This inappropriate view is certainly not good for the growth and development of writing habits at school.

Actually the constraints of other factors cannot be ignored, such as the environment and the role of parents. However, these two factors are not directly involved in writing activities. The five things described above seem to be obstacles that are often encountered in writing activities. which in turn creates conditions for learning to write that do not support the development and development of the writing potential of learners. 


\subsection{Efforts for Improvement}

Even though there is a vicious circle and obstacles around the teaching of writing, it does not mean that there is a possibility for improvement efforts in the future. Through these improvement efforts, it is hoped that writing learning will be able to develop the writing potential of students. Thus, students who are skilled in expressing their ideas and thoughts are born in good writing, both in the form of scientific and non-scientific papers.

At the point of learning conditions, writing has been stated several things that are not beneficial to the effectiveness of learning to write. In this regard, the following are some of the improvements that can be taken to minimize the weaknesses that exist around learning to write.

The first is curriculum improvement. Some teachers think that our current curriculum is very dense with material to be taught. In this regard, the Government through the Ministry of National Education should always try to evaluate the implementation of the current curriculum. The government must pick up the ball and solicit various inputs from several related parties, such as teachers, students, parents, education observers, and others. Whatever the form, all these inputs must be observed and used as material for evaluation. If necessary, it is appropriate to invite the parties mentioned above (especially the teachers). Sitting together discussing curriculum issues is very appropriate to do in order to create a more applicable curriculum. In this way, it is hoped that all weaknesses around students' writing skills can be minimized or eliminated.

Curriculum in other fields of study should also provide opportunities to empower students in the writing process. With the emphasis on writing activities in each curriculum, it is hoped that students are encouraged and motivated to pursue writing activities, This will ultimately produce students who are skilled in writing.

The second is for teachers who generally do not have a good foundation of knowledge and ability in writing. In this regard, teachers in the field of Indonesian studies should have the right approach in viewing writing. The right approach will have implications for the behavior of teachers in the classroom when fostering learning activities. Actually, the curriculum has directed teachers to be active in writing activities, namely teaching students to write, not teaching writing theory. Writing, correcting writing, discussing it, and improving writing (rewriting), is the right policy to be applied by teachers in learning. For writing theory, the teacher can assign students with reading reports. The explanation of this theory can be done when or at the same time as discussing students' writing.

Apart from the things above, the insight and experience of teachers about writing are also always improved. Participate in various trainings, seminars, workshops, and everything related to writing activities is a routine agenda that must be followed by Indonesian language teachers. It would be better if the presence of the teacher was as a presenter or resource person. Teachers must realize that their role is very large in determining whether their students will be skilled or not in writing.

Apart from teachers in the field of Indonesian language studies, teachers in other fields of study should always cultivate a positive attitude towards the world of writing. More than that, they should realize that it is also their responsibility to proficient students in writing. It is not a responsibility that is only borne by teachers in the field of Indonesian language studies. The cooperation of these teachers in developing students' writing skills (of course more emphasis on teachers in the field of Indonesian studies), is expected to improve students' writing skills.

The third solution is to change the approach, strategy and method of learning to write. In this regard, all these errors must be thrown away or scraped away. The orientation of learning to write should be directed to the act of writing. The approach used to writing must be shifted from theory to practice. If this approach has been replaced, the teacher's behavior in the classroom will exaggerate the portion of writing practice rather than explaining the theory of writing.

The ideal portion ratio between theory and practice in learning to write is between 25:75 and 40:60. This means that the portion of writing practice must be more than the portion of writing theory. The higher the portion of writing practice, the faster the person will achieve writing skills. This should be realized by every teacher who fosters learning to write. Writing practice is very necessary in every writing lesson. Only by practicing and correcting the results of these exercises a student will be skilled at writing. Therefore, training and familiarizing students with routine writing activities is the key.

Fourth is student's understanding about writing and language. In general, students' understanding of writing 
theory is not very good. For this, the teacher must be able to observe it wisely. That is, teachers should not be too burdened with these obstacles. If the teacher is too focused on it, it is feared that the learning he fosters will focus on the theoretical aspect. If this happens, the expected writing skills will not be easily realized. Teachers should be able to create certain conditions (conditioning), so that students are "forced" to understand and be skilled at writing.

Fifth is the school factor. Schools should pay more attention to writing activities by their academic community. The school's concern for writing activities should always be increased from time to time. Only in this way, writing activities can thrive in the school.

The improvement and improvement of the quality of teachers in various aspects seems to need special attention. Teachers play an important role in improving students' writing quality. Because of their large role, teachers should always (1) improve their approach to writing, (2) improve their competence and performance in writing, (3) not only "present" about writing theory, but train students to be able to produce various forms of writing (4) always motivate themselves to be familiar with the world of writing, and (5) enhance their involvement in various writing activities.

The thing that is no less important in fostering and developing writing skills is the scientific writing competition. Every year students and teachers should be involved with the competition. In any case, schools must have a concern in fostering and developing the writing potential of teachers and students. With these various policies, it is hoped that the writing potential of students can be better nurtured and developed.

\section{CONCLUSION}

The rapid development of science and technology requires everyone to work harder. This hard work is also required in the world of education. Once we are careless to follow the development of science and technology then a series of lags will be waiting for us.

In order to anticipate these developments, the pattern of student development must be more permanent, complex, and leads to coaching that can be developed at a higher level of education (continuous coaching). One of the things that need to be considered in the series of coaching is the development of language skills, specifically written language.

The following proverb still resonates: "When you are little, it was taught. When you grow up, it will be carried away. When you are old, it will not be forgotten". We also often hear "Learning as a child is like carving on water". The two wise words above can be used to guide how important early training is. We are aware that coaching on writing from scratch is very complex. However, we also believe that goodwill and hard work will definitely pay off.

\section{REFERENCES}

[1] Badudu, J.S, 1985, Cakrawala Bahasa Indonesia, Jakarta : Gramedia.

[2] Akhadiah, Sabarti dkk.. 1990. Pembinaan Kemampuan Menulis Bahasa Indonesia, Jakarta: Erlangga.

[3] Rusyana, Yus. 1988. Menulis sebagai Keterampilan Berbahasa. Bandung: Angkasa

[4] Tarigan, Hendry Guntur, 1983. Menulis sebagai suatu keterampilan Berbahasa. Bandung: Angkasa.

[5] Costa, A.L., 1985. Developing Minds (A Resource Book for Theaching Thinking). Alexandria, Virginia : The Association for Supervision and Curriculum Development.

[6] Harris, Davis P., 1977, Testing English as a Secon Languange, New Delhi : Tata McGraw Hill Publishing Company. 